\section{Radioprotective Effect of Sodium Selenite on Developing Teeth}

Ellen Gaby Neves ${ }^{1}$, Flávia Maria de Moraes Ramos-Perez², Deborah Queiroz

Freitas $^{1}$, Frab Norberto Bóscolo ${ }^{1}$, Solange Maria Almeida ${ }^{1}$
'Department of Oral Diagnosis, Oral Radiology Area, Piracicaba School of Dentistry, UNICAMP - University of Campinas, Piracicaba, SP, Brazil ${ }^{2}$ Department of Clinical and Preventive Dentistry, UFPE - Federal University of Pernambuco, Recife, PE, Brasil

Correspondence: Deborah Queiroz Freitas, Avenida Limeira, 901, Areião, 13414-400 Piracicaba, SP, Brasil. Tel: +55-19-2106-5329. e-mail: deborah@fop.unicamp.br

Key Words: radiotherapy, dental enamel, selenium.

\section{Introduction}

Radiotherapy is a treatment frequently used for malignant tumors. The success of radiotherapy depends on both the adequate dose of radiation and minimization of the adverse effects that radiation may cause in the organism.

Various alterations may develop in the irradiated organism, such as cerebral, renal, maxillomandibular complex alterations (1), xerostomia, osteoradionecrosis, mucositis and disturbances in the growth and development of teeth (2). Institution of oncological therapy at the stage of morphodifferentiation may cause alteration of the cells involved in odontogenesis and consequent delay and changes in tooth development (3).

Dental enamel is a highly mineralized tissue formed by hydroxyapatite crystals. Its formation occurs extracellularly by cells called ameloblasts, which produce proteins that gather in an ordered manner (4), originating a temporary matrix with the important function of controlling the growth, morphology and orientation of the crystals (5). Defects in enamel formation are among the most common alterations in human dentition.

Currently, pediatric patients have been successfully treated against cancer by means of radiotherapy of the head and neck. However, these children can develop dental alterations, particularly those who were irradiated before 5 years of age (3) or during intra-uterine life, when the teeth were in the stage of formation.

Antioxidant substances have been used to minimize the damage caused by radiation in healthy tissues. Among the existing radioprotectors, selenium acts on the peroxidase glutathione enzyme $(6,7)$, reducing the peroxides in the tissue by causing their destruction (8). The aim of this study was to evaluate the effect of sodium selenite on the development of the molars of offspring of rats irradiated during odontogenesis.

\section{Material and Methods}

The research protocol was approved by the Ethics Commission on Animal Experimentation of the University of Campinas, Brazil (Protocol \#1250-1). Twenty female rats (Rattus norvegicus albinus, Wistar) were selected for the induction of pregnancy to obtain an offspring of 64 pups for study. The rats were housed in polycarbonate cages and maintained under climate-controlled conditions (12$\mathrm{h}$ light/dark cycles and thermostatically regulated room temperature). During the experimental period, the animals were fed solid rat chow and water ad libitum.

First, the fertile period of the rats (also known as estrous cycle) was established. This cycle has a mean duration of 4 to 5 days and is characterized by four distinct phases determined by the cell types observed in the vaginal smear: proestrus, estrus, metestrus and diestrus. The estrus stage is the most fertile phase of the rat.

Once the fertile period (estrus phase) was established, the rats were isolated in individual cages together with a male for mating during the night period. In the morning, the first day of pregnancy was determined by the presence of the vaginal plug in addition to seeing spermatozoids in 
another vaginal smear. After this, the pregnant rats were randomly divided into 4 experimental groups: control, irradiated, selenium and selenium/irradiated.

At 18 days of pregnancy, the animals of the selenium and selenium/irradiated groups received $0.3 \mathrm{mg} \mathrm{Se} / \mathrm{kg}$ body weight of sodium selenite (Merck KgaA, Darmstadt, Germany) administered intraperitoneally. At 19 days of gestation (the bell stage of tooth development), the rats of the irradiated and selenium/irradiated groups were submitted to a single dose of $4 \mathrm{~Gy}$ of $\mathrm{x}$ radiation in the abdominal region. Irradiation was performed in a Varian model Clinac 6/100 linear accelerator (Varian Medical Systems, Palo Alto, CA, USA) with source target distance of $100 \mathrm{~cm}$.

The rat pups were sacrificed at 3, 4 and 30 days after birth. Five animals per group at 3 and 4 days were used for evaluation of the birefringence of the enamel organic matrix, while six pups per group at 30 days were used for evaluation of the intercuspal distances of the maxillary and mandibular first molars.

The birefringence of the enamel organic matrix was evaluated with a polarization microscope (Zeiss Axiolab; Zeiss, Jena, Germany) and evaluation of the intercuspal distances of the molars was performed with a scanning electron microscope (Zeiss DSM 940A; Zeiss).

The data were subjected to two-way (selenium and irradiation) ANOVA and Tukey's test with the significance level set at $p<0.05$.

\section{Results}

\section{Birefringence Analysis of the Enamel Organic Matrix of Rat First Molars}

\section{Qualitative Evaluation}

In the animals at 3 and 4 days, bright and continual strong birefringence was obtained in the region of the secretory enamel in the control group; but at 4 days the thickness was superior to the one found at 3 days. The selenium group exhibited regions with absence of

Table 1. Means and standard deviations of optical retard values (nm) for the groups at 3 and 4 days

\begin{tabular}{lccc}
\hline Period & Selenium & Irradiated & Non-lrradiated \\
\hline \multirow{2}{*}{3 Days } & Yes & $3.00(1.58) \mathrm{Ba}$ & $5.97(0.36) \mathrm{Aa}$ \\
& No & $3.84(0.62) \mathrm{Ba}$ & $7.25(1.89) \mathrm{Aa}$ \\
\multirow{3}{*}{4 Days } & Yes & $3.00(1.58) \mathrm{Bb}$ & $7.41(1.29) \mathrm{Ab}$ \\
& No & $5.17(0.81) \mathrm{Ba}$ & $13.67(1.01) \mathrm{Aa}$ \\
\hline
\end{tabular}

Means followed by different lowercase letters in the same column and uppercase letters in the same row, for each time, differ statistically by ANOVA $(\mathrm{p}<0.05)$. brightness and others with reduced birefringence, indicated by a decreased brightness in comparison with the control group. The irradiated group presented reduced thickness and irregularity in the secretory enamel region, with areas of very low birefringence corresponding to low brightness. The selenium/irradiated group was similar to the irradiated group, as regards the thickness and irregularity of the enamel organic matrix region in 3 days. At 4 days, this group exhibited a discrete increase in brightness in comparison with the irradiated group, but also presented regions with absence of brightness.

\section{Quantitative Evaluation}

At 3 and 4 days, a reduction was observed in the optical retard values for the irradiated groups (selenium/irradiated and irradiated) in comparison with the non-irradiated groups (control and selenium), with a statistically significant difference between them (Table 1).

Comparing the selenium/irradiated and irradiated groups, no statistically significant difference was observed at 3 days. In the 4-day animals, statistical difference was observed between such groups; however, no radioprotection was detected, since the irradiated group presented a higher optical retard value than the selenium/irradiated group.

\section{Morphological Analysis of the Rat First Molars by Scanning Electron Microscopy}

\section{Quantitative Evaluation}

The means of the measurements of the intercuspal distances of the maxillary and mandibular first molar crowns are shown in Tables 2 and 3, respectively. A reduction was noticed in the mesiodistal intercuspal distances in

Table 2. Means and standard deviations of the intercuspal distance measurements of maxillary first molar crowns at 30 days $(\mathrm{mm})$

\begin{tabular}{lccc}
\hline $\begin{array}{l}\text { Intercuspal } \\
\text { distance }\end{array}$ & Selenium & lrradiated & Non-lrradiated \\
\hline Mesiodistal & Yes & $2.15(0.10) \mathrm{Aa}$ & $2.34(0.08) \mathrm{Aa}$ \\
& No & $1.86(0.22) \mathrm{Bb}$ & $2.53(0.25) \mathrm{Aa}$ \\
$\begin{array}{l}\text { Bucco-palatal/ } \\
\text { mesial }\end{array}$ & Yes & $0.80(0.12) \mathrm{Ba}$ & $1.26(0.05) \mathrm{Aa}$ \\
$\begin{array}{l}\text { Bucco-palatal/ } \\
\text { central }\end{array}$ & Yes & $0.84(0.31) \mathrm{Ba}$ & $1.29(0.08) \mathrm{Aa}$ \\
$\begin{array}{l}\text { Bucco-palatal/ } \\
\text { distal }\end{array}$ & Yes & $1.28(0.13) \mathrm{Ba}$ & $1.55(0.07) \mathrm{Aa}$ \\
\hline
\end{tabular}

Means followed by different lowercase letters in the same column and uppercase letters in the same row, for each time, differ statistically by ANOVA $(\mathrm{p}<0.05)$. 
the irradiated group, demonstrating a delay in tooth development caused by ionizing radiation. There was no statistically significant difference $(p>0.05)$ between the selenium/irradiated and irradiated groups in the buccopalatal/lingual-mesial intercuspal distances of the teeth.

The results show reduction in the bucco-palatal/lingualcentral intercuspal measurements of the irradiated group in comparison with the selenium/irradiated group, however, without statistical difference between the maxillary and mandibular molars.

As the bucco-palatal/lingual distances of the distal cusps of the maxillary and mandibular molars was observed, a reduction was also noticed in the measurements of the irradiated group in comparison with the selenium/ irradiated group.

\section{Discussion}

Odontogenesis is the process of tooth development, which initiates with the formation of the tooth bud, followed by the cap and bell stages of development, followed by the laying down of enamel and dentine over the tooth crown (9). The histodifferentiation of the ameloblasts of albino rat first molars occurs at 20 intrauterine days (10).

Several external factors may affect the formation of dental tissues. Among these may be mentioned the ionizing radiation used in radiodiagnosis as well as in the treatment of malignant tumors. There is first an interaction between the ionizing radiation and the tissue. This interaction results in changes of biologic molecules after seconds or hours. Consequently, the molecular alterations may cause changes in cells and organisms, which persist for hours and possibly for generations. If the cells are modified, such changes may lead to the development of disturbances in the exposed

Table 3. Means and standard deviations of the intercuspal distance measurements of mandibular first molar crowns at 30 days $(\mathrm{mm})$

\begin{tabular}{lccc}
\hline $\begin{array}{l}\text { lntercuspal } \\
\text { distance }\end{array}$ & Selenium & lrradiated & Non-lradiated \\
\hline Mesiodistal & Yes & $1.95(0.06) \mathrm{Ba}$ & $2.08(0.08) \mathrm{Aa}$ \\
& No & $1.92(0.09) \mathrm{Ba}$ & $2.08(0.19) \mathrm{Aa}$ \\
$\begin{array}{l}\text { Bucco-lingual/ } \\
\text { mesial }\end{array}$ & Yes & $1.25(0.02) \mathrm{Aa}$ & $1.11(0.06) \mathrm{Ba}$ \\
$\begin{array}{l}\text { Bucco-lingual/ } \\
\text { central }\end{array}$ & Yes & $1.17(0.09) \mathrm{Aa}$ & $1.08(0.06) \mathrm{Aa}$ \\
$\begin{array}{l}\text { Bucco-lingual/ } \\
\text { distal }\end{array}$ & Yes & $1.22(0.05) \mathrm{Aa}$ & $1.23(0.03) \mathrm{Aa}$ \\
\hline
\end{tabular}

Means followed by different lowercase letters in the same column and uppercase letters in the same row, for each time, differ statistically by ANOVA $(p<0.05)$. individual or his/her descendants (11).

Kaste et al. (12) studied patients who had cancer in the childhood and received a radiation dose according to the type of tumor and also found dental alterations, such as microdontia, hypodontia, enamel hypoplasia and abnormal development of the roots. The severity of the disturbances may be due mainly to the used radiation dose in radiotherapy and age of the patient at the time of treatment, since children treated before the age of 5 years presented more severe dental abnormalities (13).

Selenium is an essential nutrient for many species of animals, including humans (14). It is also a constituent of the peroxidase glutathione enzyme (6-7), and this may be the explanation for its radioprotective effect. Selenium deficiency leads to a reduction in glutathione peroxidase activity (15) because it is considered an essential component of this enzyme. Therefore, sodium selenite was used in this study to minimize the possible dental anomalies induced by radiation and compare with the dental morphology of the control group animals.

Traditionally, selenium has been associated with protection against radiation because of its antioxidant properties (16), capturing the free radicals resulting from the ionization caused by radiation. However, in this study the selenium/irradiated and irradiated groups did not differ in the statistical analysis. The birefringence brightness of enamel organic matrix in the selenium/irradiated group was also similar to the irradiated group, demonstrating that the sodium selenite did not provide radioprotection in 3- and 4- day old animals, with the used doses.

Amelogenin is the main protein in the enamel organic matrix, representing over $90 \%$ of the protein content in this tissue (17). Accordingly, in the present study, analysis of the first molar of rats showed that the enamel organic matrix in 4-day-old animals in the control group exhibited strong birefringence in the secretory enamel areas.

Of all the intercuspal measurements, the selenium/ irradiated and irradiated differed statistically only in the mesiodistal linear measurements and in the bucco-palatal measurements of the distal cusps of the maxillary molars. This difference was not observed in the measurements of the mandibular teeth, once again demonstrating that sodium selenite did not have a radioprotective action. This finding is in agreement with the study by Rocha et al. (6), in which sodium selenite was not an effective radioprotector at 7 and 14 days of evaluation in bone tissue, but it is contrary to the outcomes of different studies $(7,8,16,18-21)$.

In the above-mentioned groups, the statistical difference occurred in most of the measurements of maxillary teeth may be explained, since their formation occurs around 24 hours after formation of the mandibular teeth (10). These results may also be justified by the individual response of 
each animal, supposing that not all animals were in the same stage of odontogenesis at the time of irradiation. Therefore, if the irradiation did not occur in the same period of formation for the maxillary and mandibular teeth, the resulting damage was different and could have been less in the mandibular teeth, consequently leading to the lack of radioprotection by sodium selenite.

Moreover, the used dose of sodium selenite $(0.3 \mathrm{mg} /$ $\mathrm{kg}$ body weight of the animal) could possibly be low and insufficient to provide protection to the irradiated tissues. However, it was chosen due to its application in pregnant rats and because selenium possibly presents adverse effects on the organism by its toxicity, a characteristic observed in several studies that used high doses of selenium $(14,20,22-$ 25).

Buntzel et al. (7) conducted a study in human patients with cancer undergoing radiotherapy in which a $500 \mu \mathrm{g}$ sodium selenite dose was administered to the subjects, and found that the replacement of selenium could be able to reduce the deleterious effects of radiation, although with limited effects, since these were only observed in the reduced loss of taste and dysphagia. However, no studies have yet been found in pregnant patients.

In conclusion, within the used experimental conditions, sodium selenite did not provide radioprotective action on the dental development of offspring of rats irradiated during odontogenesis and presented toxicity in the initial evaluation times. In view of the number of studies in this area, it is expected to obtain favorable and applicable results with a dose of sodium selenite that protects against the deleterious effects of radiation, diminishing the alterations caused in healthy tissues of patients treated by radiotherapy, thus increasing the quality and expectation of life of these patients.

\section{Resumo}

Agentes radioprotetores, como o selênio, são utilizados para reduzir os danos causados pela radiação nos tecidos sadios. 0 objetivo nesse estudo foi avaliar o efeito do selenito de sódio no desenvolvimento de molares de filhotes de ratas irradiadas. Vinte ratas grávidas foram aleatoriamente divididas em 4 grupos: controle, irradiado, selênio e selênio/irradiado. Os animais dos grupos selênio e selênio/irradiado receberam $0.3 \mathrm{mg} / \mathrm{kg}$ de selenito de sódio aos 18 dias de gestação. Os animais dos grupos irradiado e selênio/irradiado receberam dose única de $4 \mathrm{~Gy}$ de radiação $X$ na região abdominal aos 19 dias de gestação. Os filhotes foram sacrificados aos 3 e 4 dias após o nascimento para avaliação da birrefringência da matriz orgânica do esmalte, e aos 30 dias para avaliação das dimensões dos molares. 0 s resultados do grupo selênio/irradiado foram similares aos do irradiado, tanto em relação à espessura e irregularidade região da matriz orgânica do esmalte quanto às dimensões dos molares. Dessa forma, foi possível concluir que o selenito de sódio não exerceu ação radioprotetora no desenvolvimento de molares de filhotes de ratas irradiadas durante a odontogênese e apresentou efeito tóxico nos tempos iniciais.

\section{References}

1. Bang DW, Lee JH, Oh H, Kim SR, Kim TH, Lee YS, et al.. Dose-incidence relationships on the prenatal effects of gamma-radiation in mice. J Vet Sci 2002;3:7-11.

2. Niehoff $P$, Springer IN, Açil $Y$, Lange $A$, Marget $M$, Roldán JC, et al.. HDR brachytherapy irradiation of the jaw - as a new experimental model of radiogenic bone damage. J Craniomaxillofac Surg 2008;36:203-209.

3. Lopes NN, Petrilli AS, Caran EM, França CM, Chilvarquer I, Lederman H. Dental abnormalities in children submitted to antineoplastic therapy. J Dent Child 2006;73:140-145.

4. Espírito Santo AR, Bartlett JD, Gibson CW, Li Y, Kulkarni AB, et al.. Amelogenin- and enamelysin (Mmp-20)-deficient mice display altered birefringence in the secretory-stage enamel organic extracellular matrix. Connect Tissue Res 2007;48:39-45.

5. Moradian-Oldak J, lijima M, Bouropoulos N, Wen HB. Assembly of amelogenin proteolytic products and control of octacalcium phosphate crystal morphology. Connect Tissue Res 2003;44 Suppl 1:58-64.

6. Rocha AS, Ramos-Perez FM, Bóscolo FN, Manzi FR, Chicarelo M, Almeida SM. Effect of sodium selenite on bone repair in tibiae of irradiated rats. Braz Dent J 2009;20:186-190.

7. Büntzel J, Micke O, Kisters K, Bruns F, Glatzel M, Schönekaes K, et al.. Selenium substitution during radiotherapy of solid tumors - laboratory data from two observation studies in gynaecological and head and neck cancer patients. Anticancer Res 2010;30:1783-1786.

8. Sagowski C, Wenzel S, Jenicke L, Metternich FU, Jaehne M. Sodium selenite is a potent radioprotector of the salivary glands of the rat: acute effects on the morphology and parenchymal function during fractioned irradiation. Eur Arch Otorhinolaryngol 2005;262:459-464.

9. Townsend G, Bockmann M, Hughes T, Brook A. Genetic, environmental and epigenetic influences on variation in human tooth number, size and shape. Odontology 2012;100:1-9.

10. Gartner LP, Hiatt JL, Provenza DV. Effects of ionizing radiation on incisor development of the prenatal mouse. Acta Anat 1977;98:367375.

11. Trosko JE, Chang CC, Upham BL, Tai MH. Low-dose ionizing radiation: induction of differential intracellular signalling possibly affecting intercellular communication. Radiat Environ Biophys 2005;44:3-9.

12. Kaste SC, Goodman $P$, Leisenring $W$, Stovall M, Hayashi RJ, Yeazel $M$, et al.. Impact of radiation and chemotherapy on risk of dental abnormalities: a report from the Childhood Cancer Survivor Study. Cancer 2009;115:5817-5827.

13. Sonis AL, Tarbell N, Valachovic RW, Gelber R, Schwenn M, Sallan S. Dentofacial development in long-term survivors of acute lymphoblastic leukemia. A comparison of three treatment modalities. Cancer 1990;66:2645-2652.

14. Stewart MS, Spallholz JE, Neldner KH, Pence BC. Selenium compounds have disparate abilities to impose oxidative stress and induce apoptosis. Free Radic Biol Med 1999;26:42-48.

15. Flohe L, Günzler WA, Schock HH. Glutathione peroxidase: a selenoenzyme. FEBS Lett 1973;32:132-134

16. Rafferty TS, McKenzie RC, Hunter JA, Howie AF, Arthur JR, Nicol F, et al.. Differential expression of selenoproteins by human skin cells and protection by selenium from UVB-radiation-induced cell death. Biochem J 1998;332:231-236.

17. Espírito Santo AR, Novaes PD, Line SR. Anisotropic properties of the enamel organic extracellular matrix. Eur J Oral Sci 2006;114 Suppl 1:333-337.

18. Mutlu-Türkoglu U, Erbil Y, Oztezcan S, Olgaç V, Toker G, Uysal M. The effect of selenium and/or vitamin $E$ treatments on radiation-induced intestinal injury in rats. Life Sci 2000;66:1905-1913.

19. Pontual ML, Tuji FM, Barros SP, Bóscolo FN, Novaes PD, de Almeida SM. Ultrastructural evaluation of the radioprotective effect of sodium selenite on submandibular glands in rats. J Appl Oral Sci 2007;15:162168.

20. Tuji FM, Pontual ML, Barros SP, Almeida SM, Bóscolo FN. Ultrastructural assessment of the radioprotective effects of sodium selenite on parotid glands in rats. J Oral Sci 2010;52:369-375.

21. Freitas, DQ, Ramos-Perez FMM, Neves EG, Marques MR, Bóscolo FN, Almeida SM. Radioprotective effect of sodium selenite on bone repair in the tibia of ovariectomized rats. Braz Dent J 2012;23:723-728. 
22. Sieber F, Muir $S A$, Cohen $E P$, North $P E$, Fish $B L$, Irving $A A$, et al.. Highdose selenium for the mitigation of radiation injury: a pilot study in a rat model. Radiat Res 2009;171:368-373.

23. Wu J, Lyons GH, Graham RD, Fenech MF. The effect of selenium, as selenomethionine, on genome stability and cytotoxicity in human lymphocytes measured using the cytokinesis-block micronucleus cytome assay. Mutagenesis 2009;24:225-232.

24. MacFarquhar JK, Broussard DL, Melstrom P, Hutchinson R, Wolkin A,
Martin C, et al.. Acute selenium toxicity associated with a dietary supplement. Arch Intern Med 2010;170:256-261.

25. Raines AM, Sunde RA. Selenium toxicity but not deficient or supernutritional selenium status vastly alters the transcriptome in rodents. BMC Genomics 2011;12:26.

Received April 8, 2013 Accepted May 17, 2013 